\title{
Childbearing among Polish migrant women and their descendants in Sweden: an origin-destination country approach
}

\author{
Jonathan Lindström ${ }^{1}\left(\mathbb{D} \cdot\right.$ Eleonora Mussino ${ }^{1}\left[\right.$ ] Livia Sz. Oláh ${ }^{1}$
}

Accepted: 7 November 2021 / Published online: 7 March 2022

(c) The Author(s) 2022

\begin{abstract}
This paper examines the childbearing behaviour of Polish migrant women and their descendants in Sweden. Also considering stayers in the country of origin, we rely on a country-of-origin and country-of-destination approach in a careful examination regarding the relevance of three hypotheses on migrant fertility: the socialisation, selection, and adaptation hypotheses. We analyse the transitions to first and second births based on a piecewise exponential model, using Swedish register data and the Polish Generations and Gender Survey (GGS) first wave. The results support the socialisation hypothesis, as the Polish stayers and the first-generation Polish migrants have their first child at younger ages and are less likely to remain childless than the other groups but are also more likely to not proceed to a second child, unlike the Swedish natives and the second generation. We find partial support for the selection hypothesis. Descriptively, we observe signs of selection into migration based on education, cohort, and marital status. Additionally, our study shows that the impact of marriage varies between stayers and migrants, in the first-birth transition, suggesting selection into migration when it comes to unobserved characteristics as well. The adaptation hypothesis is also supported, as the fertility behaviour of the second generation more closely resembles that of the Swedish natives than that of the first generation and differs more from that of the Polish stayers in terms of both quantum and timing of the first and second births.
\end{abstract}

Keywords Immigrant fertility $\cdot$ Poland $\cdot$ Sweden $\cdot$ Adaptation $\cdot$ Socialisation · Selection

Eleonora Mussino

eleonora.mussino@sociology.su.se

1 Dept. of Sociology, SUDA, Stockholm University, 10691 Stockholm, Sweden 


\section{Introduction}

Recent decades have seen a substantial increase in the number of migrants moving from low-fertility countries, including those in Eastern Europe, to other European countries. However, the knowledge about such migrants' fertility behaviour is still modest (see e.g., Andersson et al., 2017; Pailhé, 2017; Puur et al., 2017, Van Landshoot et al., 2017 as exceptions) and mainly focuses on Polish migrants in the UK (e.g., Lübke, 2015; Marczak et al., 2018; Waller et al., 2014). In later studies (see Lübke, 2015), however, it has been suggested that Polish migrants' fertility should also be studied within a destination context with more generous family policies. While Tønnessen and Mussino (2020) examine Polish migrants in a Norwegian context from a macro perspective, this study will advance the research following an individual (micro) perspective.

As most migrants are of childbearing age, their (potential) contribution to the number of births in destination countries is hardly negligible (Andersson, 2004; Sobotka, 2008). In addition, as some scholars argue, immigrants' fertility behaviour can be considered an indicator of their cultural integration (see Adserá \& Ferrer, 2015; Coleman, 1994; Milewski \& Mussino, 2018). Studying immigrants from low-fertility origins can greatly enhance the understanding of the mechanisms at stake, both because they might be less likely to have children prior to arrival, and because any fertility adaptation 'from below' may make it easier to disentangle the forces of adaptation from the impact of interrelated demographic events on post-migration fertility (cf. Tønnessen \& Mussino, 2020; Mussino et al., 2021).

The majority of studies on immigrant fertility have compared migrants with native women in the destination country, as pointed out by Lübke (2015), Baykara-Krumme and Milewski (2017), and Impicciatore et al., (2020). Such comparison enables an examination of the migrants' adaptation process and, to some extent, the effect of compositional differences. However, this unilateral focus is also problematic, as some proposed explanations regarding migrant fertility-namely socialisation and selection into migration-require a comparison of migrants and non-migrants (called 'stayers' in this paper) in the origin country. Several scholars (e.g., Glick, 2010; Lessard-Phillips et al., 2017; Schoenmaekers et al., 1999) have indeed stressed the need to include stayers in the analysis. This approach has been implemented in North-American research (see Choi, 2014; Frank \& Heuveline, 2005; Lindstrom \& Saucedo, 2002, 2007; Massey \& Mullan, 1984; Parrado, 2011), but less so in Europe (as exception see Baykara-Krumme \& Milewski, 2017; Güveli et al., 2016; Impicciatore et al., 2020; Lübke, 2015; Puur et al., 2017). However, results are inconsistent across studies and among different country groups (e.g., Impicciatore et al., 2020).

Given the limited, albeit rising, number of studies using a combined country-oforigin and country-of-destination design focusing on migrants from low-fertility origins, our aim is to contribute to filling this research gap. The main novelty of this study is that it examines Polish migrants as one of the largest groups moving within Europe (Eurostat, 2019) and settling in Sweden, a highest-low-fertility country (Kulu et al., 2007), relying on a combined country-of-origin and country-of-destination perspective. As Sweden became one of the main destination countries for Polish migrants when Poland joined the European Union in 2004, a study of these migrants' 
fertility behaviour in Sweden will complement the picture of Polish migrants' fertility behaviour. Sweden is also a compelling case because of the availability of high-quality longitudinal data on the demographic careers of its entire population. Moreover, as Poland and Sweden differ greatly in terms of policy-setting (e.g., Hort et al., 2016; Siemieńska \& Domaradzka, 2016; Tomescu-Dubrow et al., 2019; Wells \& Bergnéhr, 2014), the study of Polish women in these various institutional settings may also provide a better understanding of how social policies and socialisation in tandem influence immigrants' fertility behaviour.

\section{Previous research on immigrant fertility}

Previous literature offers various theoretical explanations regarding immigrant fertility behaviour (see Kulu \& González-Ferrer, 2014; Milewski, 2010b; Wilson, 2013). Here, we focus on three competing but not mutually exclusive explanations, which are of interest regarding the medium- and long-term effects of migration on fertility. By medium- and long-term effects, we simply mean that the focus is not on the timing of childbearing around the time of migration, and that we include a 'migrant generation' perspective (e.g., the first and second generations).

First, according to the socialisation hypothesis, moving to another country will not affect people's fertility behaviour, norms, values, preferences, or aspirations. This hypothesis assumes that exposure to fertility norms during childhood influences a person's future fertility behaviour and preferences. Their fertility behaviour will thus be similar to that of their peers in their country of origin. The socialisation hypothesis has been supported regarding both migrants from high-fertility contexts (e.g., Turks in West Germany, Milewski, 2010a; Moroccans and Albanians in Italy, Mussino \& Strozza, 2012) and migrants moving from low-fertility countries (e.g., Romanians in Italy, Mussino \& Strozza, 2012). It can be questioned, however, whether it is possible to assess the socialisation effect without including stayers in the analyses. Unlike the studies mentioned above, Baykara-Krumme and Milewski (2017) and Impicciatore et al., (2020) test the socialisation hypothesis by comparing migrants with stayers, but their results are inconsistent. In the former study the authors find no support for the hypothesis among Turkish migrants in Europe, while in the latter study it is supported for Moroccan migrants in Italy but not for Albanian or Ukrainian migrants.

Second, people moving from one country to another have certain characteristics that distinguish them from both the population at origin and the population at destination. This is the selection hypothesis, which suggests that migrants' fertility behaviour will be different compared to that of natives in the country of destination and that of non-migrants in the country of origin (Milewski, 2010b). The selection can reflect both observed and unobserved characteristics (Milewski, 2007) that may differ within an immigrant group over time (Frank \& Heuveline, 2005; Kahn, 1988). Observed characteristics can include education, marital status, and occupation (Bagavos et al., 2008; Kulu \& González-Ferrer, 2014; Macisco et al., 1969), while ability, aspirations, and open-mindedness are examples of unobserved characteristics (Blau, 1992; Goldstein \& Goldstein, 1983; Kahn, 1988). In Baykara-Krumme and Milewski's study (2017), the selection hypothesis is supported regarding the transition to 
first birth, as marital status can explain the difference between first-generation Turkish immigrants and Turkish stayers. In contrast, it is rejected regarding the transitions to second and third births, as the groups do not become more similar when education, marriage type, and family characteristics are controlled for.

Third, the adaptation hypothesis suggests that immigrants' fertility patterns resemble those of women in the destination country, as the current social context influences fertility behaviour (Kulu \& González-Ferrer, 2014). The adaptation hypothesis has been tested both by duration of stay (e.g., Andersson, 2004; Andersson \& Scott, 2005) and across migrant generations (e.g., Kulu et al., 2017; Kulu et al., 2019). It has received a great deal of support in research on migrants moving from high-fertility to low-fertility countries (see e.g., Dubuc, 2012 on Bangladeshi and Pakistani migrants in the UK; and Milewski 2007 on Turkish migrants in West Germany). There is also evidence of adaptation from below; in other words, migrants moving from a country with low fertility to one with higher fertility (see Nahmias, 2004, on Former-Soviet Union migrants in Israel; and Tønnessen \& Mussino, 2020, on non-family migrants from Germany, Lithuania, and Poland in Norway). The adaptation hypothesis has some shortcomings; for example, for migrants who have more than two children prior to migration it is impossible to adapt to (below) replacement fertility levels in the host country (Adserà et al. 2012; Tønnessen \& Wilson, 2020), or the birth may be strictly connected to the migration (e.g., Hoem \& Nedoluzhko, 2016). These issues can be dealt with, however, by testing the hypothesis across several migrant generations moving from low- to high-fertility countries.

A growing body of research indeed addresses second-generation migrants (e.g., Kulu et al., 2017; Kulu et al., 2019). In countries with a long history of immigration, such as the US, Canada, and Australia, a good deal of research has been conducted on immigrants' fertility and other demographic behaviour, whereas this is a relatively new topic in Europe, where the numbers of second-generation migrant women of childbearing age have been limited until quite recently (ibid.). As members of the second generation are exposed to the same values, norms, and social policies as natives are, the adaptation hypothesis can be tested across migrant generations. The literature shows evidence of adaptation among Lebanese descendants in Australia (Abbasi-Shavazi \& McDonald, 2000), among immigrants with Nordic-born parents in Sweden (Scott \& Stanfors, 2011; Statistics Sweden, 2010), and among Southeast Asian and sub-Saharan descendants in France (Pailhé, 2017). Several authors have found depressed fertility among migrant descendants, with levels even lower than those among ancestral natives (e.g., Andersson et al., 2017 for Sweden; Guarin Rojas et al., 2018 for Switzerland). In addition, Milewski (2011) shows that there are differences in fertility behaviour among second-generation Turkish migrants living in different countries, suggesting adaptation to the destination countries' fertility behaviour. However, as the second generation is considered to be exposed to preferences and values held by their parents or to be influenced by a minority subculture, regarding this group's fertility behaviour the socialisation hypothesis may be relevant to investigate alongside the hypothesis of cultural entrenchment (Kulu \& González-Ferrer, 2014; Kulu \& Hannemann, 2016; Milewski, 2011). Accordingly, second-generation Greeks and Italians in Australia exhibit preferences and values held by their parents or in line with a minority subculture, which are different from 
the mainstream social norms in Australia. In line with these results, the childbearing patterns of Russian descendants are very similar to those of their counterparts in their parents' country of origin (Puur et al., 2017).

Finally, we see interest in Polish migrants' fertility rising alongside their importance in shaping European migration from 2004 onwards. In a case study of Polish migrants in the UK, Lübke (2015) finds depressed fertility before migration and elevated fertility immediately after. Klimek (2017) finds evidence of fertility postponement among Polish migrants in Ireland, although they show higher fertility than their counterparts in Poland. Waller, Berrington, and Raymer (2014) and Gołata (2016) find slightly higher fertility among migrants than among stayers, comparing ASFRs (Age Specific Fertility Rates) and TFR (Total Fertility Rate) of Polish women in the UK and Poland. Tønnessen and Mussino (2020) show high total fertility rates for Polish migrants in Norway immediately after migration. However, Polish migrants who came for reasons other than family reunification seemed to adapt to Norwegian fertility levels from below, as higher TFR was first seen for them four years after migration (ibid.). Compared to Swedish natives, the share of women not proceeding to have a second (and third) child is higher among Polish migrants (Andersson, 2004; Andersson \& Scott, 2007). The impact of education on becoming a parent, however, is more pronounced among second-generation Polish migrants than among women of Swedish origin (Scott \& Stanfors, 2011). More specifically, women of Polish descent with low education have a substantially higher propensity of entering parenthood than their Swedish counterparts, while those who are highly educated have a lower propensity. An important shortcoming is that the Polish stayers are not included along with the Swedish natives in the analysis in the latter studies.

\section{The contexts of Sweden and Poland}

The number of Poles moving to Sweden has varied over the years, from about 1,0002,000 annually between 1968 and 2004 (Klinthäll, 2007; OECD, 2020) to over 4,000 annually after Poland entered the EU. By 2018, Poles had become the fourth largest immigrant group in Sweden, numbering 91,180 (Eurostat, 2020). Their reasons for migration have also varied, from coming as political refugees in the 1980s (Andersson \& Scott, 2005; Klinthäll, 2007) to family reasons at the beginning of the 2000s and work reasons after 2004 (Bengtsson, 2008), the last of these also explaining the increasing share of men (47\% by 2018) in this migrant group (Eurostat, 2020). Previous low return rates notwithstanding (Klinthäll, 2006), more recent economic growth in Poland has led to increasing return migration and decreasing emigration (Castles et al., 2014).

With respect to fertility regimes, there are substantial differences between Sweden and Poland. Sweden is characterised by relatively high and stable cohort fertility (around two children per woman on average), despite strongly fluctuating period fertility rates related to changes in the business cycle, the labour market, and in family policy measures (Jalovaara et al., 2019). In any case, period fertility rates have remained reasonably close to the replacement level, with the exception of the mid-/ late 1990s (Statistics Sweden, 2018). In contrast, Poland has exhibited dramatic shifts 
in both period and cohort fertility rates, especially from the early 1990s onwards. From a TFR of 2.09 then to 1.3 in 2015 , with cohort fertility also declining from about 2.0 to 1.6 , the new demographic regime has been closely linked to a declining progression of first and second births also related to postponement of births, in addition to earlier reductions in higher-order births (Eurostat, 2021; Grzenda \& Fratczak, 2018).

It has been suggested that the institutional context and family policies have played a key role in both countries' fertility developments (Billingsley \& Matysiak, 2018; Fahlén and Oláh 2013). In Sweden, around 55\% of births occur outside marriage, mostly within cohabiting relationships (OECD, 2018), and societal norms as well as gender role attitudes are highly liberal (Kaufman et al, 2017; Lesthaeghe, 2011). Guided by the principle of gender equality, Sweden has consequently facilitated the combination of paid work and family responsibilities for both women and men since the late 1960s-early 1970s. Female employment rates rank among the highest in the OECD, with extensive opportunities to work part-time, a generous and highly flexible parental leave programme, and subsidised, high-quality public childcare, which also facilitate parents' active engagement with their children from an early age, regardless of the parent's gender (Neyer, 2013). Services are prioritised in Sweden with respect to public spending on families, promoting the dual-earner/dual-carer model. In contrast, in Poland there is less emphasis on the combination of employment and family responsibilities, seen in rigid labour market structures with nearly exclusively fulltime job opportunities, a balance between cash benefits and services in the relatively low public spending on families, and limited access to inexpensive quality childcare (OECD, 2019). Also, traditional norms prevail in Poland, with an emphasis on marriage as the proper context for childbearing and low social acceptance of mothers working if they have young children (Matysiak \& Vignoli, 2013; Szelewa, 2017). The level of non-marital cohabitation has remained low in Poland, with about $25 \%$ of children born out of wedlock in recent years.

\section{Hypotheses}

Built on the theoretical approaches and previous research presented above, three hypotheses will be tested in this study:

Hypothesis 1 (H1) Despite migration experience, first-generation migrant women in Sweden exhibit fertility behaviour, in terms of timing and quantum, similar to that of stayers at origin - socialisation hypothesis.

Hypothesis $2(\mathrm{H} 2)$ The fertility behaviour of first-generation migrant women is different in regard to timing and quantum compared to that of both stayers at origin $(H 2 a)$ and natives at destination $(H 2 b)$, with some differences linked to migrant women differing in marital status, cohort, and education-selection hypothesis.

Such information has been shown to be important for fertility behaviour in general and for migrants in particular (e.g., Baykara-Krumme \& Milewski, 2017; Milewski, 
2007; Milewski, 2010a). We also focus on marital status as an indicator of an unobserved liberal value orientation of migrant women prompting them to have children out of wedlock.

Hypothesis $3(\mathrm{H} 3)$ The fertility behaviour of migrant women converges across migrant generations to the norm at destination. In this sense, the second generation, exposed to the mainstream norms and social policies during their childhood and reproductive years, have fertility behaviour similar to that of natives, in terms of timing and quantum, and more so than the first generation—adaptation hypothesis.

To test these hypotheses, we focus on the transition to first and second births as the most important birth orders shaping total fertility rates in European countries. Although having a first child is (nearly) universal in both Sweden and Poland, our results will contribute to the discussion on the timing of (first) parenthood and highlight the impact of migration on fertility, comparing migrants and stayers. In contrast, the transition to a second child is common in Sweden but less so in Poland; thus, we will highlight not only the differences between Polish migrants and (Polish) stayers but also those between Polish stayers and Swedish natives.

\section{Data and methods}

\section{Data}

We use Swedish register data and the first wave of the Polish Generations and Gender Survey (GGS) ${ }^{1}$, focusing on women born in Poland and Sweden between 1950 and 1992. Both the Swedish registers and the GGS have a longitudinal setup, which means that it is relatively easy to make the two datasets comparable. However, in selecting the study population and constructing the explanatory variables, some restrictions are needed; these are described later in this section and in the section on variables. The Swedish register data was acquired from the 'Migrant Trajectories: Geographical Mobility, Family Careers, Employment, Education, and Social Insurance in Sweden' project. The population is based on the Historical Population Registers (Historiska befolkingsregistret), a longitudinal database covering everyone who has ever been registered in Sweden. In this study, we focus specifically on women registered in Sweden in 2010.

The GGS data was collected in Poland in late 2010 to early 2011. In order to achieve a sample size of 20,000 individuals oversampling was used, with 48,000 addresses visited to reach this goal. The response rate was 55\% (Vignoli et al., 2018). To be included in the sample selection, individuals had to be Polish-speaking, aged 18-79, and living in a private household. Birth and marital histories were collected via retrospective questions. A total of 19,987 individuals participated in the survey, of whom 11,578 were women (Kotowska et al., 2019).

\footnotetext{
${ }^{1}$ (DOIs: https://doi.org/10.17026/dans-z5z-xn8g, https://doi.org/10.17026/dans-xm6-a262); see Gauthier et al. (2018) or visit the GGP website (https://www.ggp-i.org/2 for methodological details.
} 
In addition to exclusion criteria based on sex, year of birth, and country of birth, other exclusions were also made. Some women in the Polish GGS have missing information regarding their child's birth year or whether the child was biological, adopted, a foster child or a stepchild, and are therefore excluded from the analysis. Women in the Swedish registers who had puzzling marital histories, for instance marrying twice in a row without divorcing in between or marrying and divorcing on the same day, have also been excluded. Given the event-history approach of this paper, individuals with multiple marital events in the same month are excluded. As the marital status information is available from January 1, 1968 in the registers, for some women divorce or widowhood is the first registered marital event while there is no information on when they married. Some of these women are Polish migrants who married before moving to Sweden and are therefore kept in the analysis, while Swedish-born women with divorce or widowhood as their first marital event are dropped. Polish migrants with no information on marital status at migration are also excluded.

The registers contain no information on children who have never been registered in Sweden. More specifically, if a Polish migrant woman moves to Sweden and leaves her children in Poland permanently, these children will not be registered in Sweden. However, only about $2 \%$ of the women migrating to Sweden before the age of 40 do not bring their children (see Mussino et al., 2018). To minimise the problem of unregistered children living in their country of origin, women migrating after the age of 40 are excluded from the analysis. Women who already had a child at migration or gave birth the same month they migrated are excluded from the first-birth analysis but are included in the analysis on second birth. To avoid this drop causing selection problems in the analysis on the first child, these women are included in the descriptive analysis (see Table 1). Given the lack of consensus on the 1.5-generation and our preliminary results (see discussion in supplemental appendix), migrants younger than 15 are not included in our analysis, meaning that the first-generation Polish migrants analysed in this paper migrated between the ages of 15 and 39. For a detailed description of how many individuals were dropped, or censored, see Table A1 in the supplemental appendix. The Polish GGS sample is not fully representative of its population. However, the weights provided reduce the deviation between the sample and the population in terms of age, gender, region, and household size, while increasing the deviation for educational level (Fokkema et al., 2016). As the deviation is reduced for all characteristics except education, we use weights for the Polish stayers in all analyses.

Altogether, the study population consists of $1,797,053$ women. Most of these women originate from the Swedish registers; more specifically, 1,757,036 were born in Sweden to two Swedish-born parents (Swedish natives). A total of 22,496 individuals were Polish migrants who migrated between the ages of 15 and 39 (first-generation); 9,562 were born in Sweden to at least one parent who was born in Poland (second generation); and finally, $7,959^{2}$ derive from the Polish GGS and represent the Polish stayers (i.e., born and lived in Poland in late 2010-early 2011).

\footnotetext{
${ }^{2}$ The number of respondents is lower compared to the initial number $(11,578)$ because we only consider women born during the period 1950-1992.
} 
Table 1 Descriptive overview of sample for first-birth transition, $\%$ by migrant group. Data: Swedish register data and Polish GGS
Notes: $\quad \mathrm{G} 1 *=$ first-generation

Polish migrants, including women already with children at migration, $\mathrm{G} 1=$ first generation, $\mathrm{G} 2=$ second generation.

\begin{tabular}{|c|c|c|c|c|c|}
\hline & $\begin{array}{l}\text { Swedish } \\
\text { natives }\end{array}$ & G1* & G1 & G2 & $\begin{array}{l}\text { Polish } \\
\text { stayers }\end{array}$ \\
\hline \multicolumn{6}{|l|}{ Cohort } \\
\hline $1950-1959$ & 23 & 30 & 29 & 13 & 19 \\
\hline 1960-1969 & 25 & 18 & 17 & 8 & 22 \\
\hline 1970-1979 & 22 & 27 & 24 & 21 & 28 \\
\hline 1980-1992 & 30 & 25 & 30 & 58 & 31 \\
\hline \multicolumn{6}{|l|}{ Education in 2010} \\
\hline Low & 12 & 14 & 11 & 11 & 8 \\
\hline Medium & 44 & 35 & 34 & 35 & 58 \\
\hline High & 33 & 36 & 40 & 28 & 26 \\
\hline In education & 11 & 5 & 5 & 25 & 8 \\
\hline Missing & 0 & 10 & 10 & 1 & 0 \\
\hline \multicolumn{6}{|l|}{ Marital status in 2010} \\
\hline Single & 52 & 23 & 31 & 70 & 26 \\
\hline Married & 38 & 51 & 46 & 24 & 61 \\
\hline Divorced/widowed & 10 & 26 & 23 & 6 & 13 \\
\hline \multicolumn{6}{|l|}{ Age at migration } \\
\hline $15-19$ & & 8 & 12 & & \\
\hline $20-24$ & & 29 & 37 & & \\
\hline $25-29$ & & 33 & 34 & & \\
\hline $30-34$ & & 19 & 12 & & \\
\hline $35-39$ & & 11 & 5 & & \\
\hline $\mathrm{N}$ & $1,757,036$ & 22,496 & 14,525 & 9,562 & 7,959 \\
\hline
\end{tabular}

\section{Method}

In order to make possible a direct comparison between the women in the GGS and in the Swedish registers, the two datasets have been pooled. We apply event-history techniques to analyse the transitions to first and second births separately. These methods are frequently used in immigrant fertility research (see e.g., Andersson, 2004; Baykara-Krumme \& Milewski, 2017) and are appropriate for our aim as they provide information about whether an event takes place as well as its timing (Mills, 2011), without requiring completed fertility biographies (Blossfeld et al. 2007). A piecewise exponential model is our tool of analysis as it allows the baseline to change over time while being kept constant within a fixed interval. Control variables are included stepwise to monitor their influence on the baseline and the other covariates. In addition, Kaplan-Meier survival curves are estimated, which, in the first-birth analysis, estimates the proportion of women who remain childless at different ages. In the secondbirth analysis it estimates the proportion of women who remain one-child mothers.

For the first-birth analysis the process time starts at age 15, following the conventional demographic approach to reproductive ages (Coale \& Trussell, 1974). Thus, we left-censor all women who gave birth before age 15 . As the registers only contain information about marriages entered into in 1968 or thereafter, January 1968 is used as the entry for women whose process starts before 1968 (this does not apply to the Polish stayers, who always enter observation at age 15). First births in Sweden prior to 1968 are therefore left-censored even if the mother is older than 15; but as the 
oldest women in this study were born in 1950, such cases are few. Because the firstgeneration Polish migrants enter observation upon arrival in Sweden, the time at risk prior to migration is not considered. Regardless which of the four groups a person belongs to, all women in the analysis are right-censored at first birth, at age 45, on December 31, 2010 (at the time of the interview of the Polish stayers, i.e., late 2010early 2011) or at emigration, whichever comes first. As for individuals registered in Sweden in 2010, some emigrated first and then re-immigrated. Such individuals are right-censored at emigration and are not considered at risk again when they return (in line with Andersson, 2004). For the Polish GGS no one was censored for emigration, given a lack of information on this. As the data contains individuals who lived in Sweden on December 31, 2010 and individuals who participated in the Polish GGS, there is no need to right-censor for death.

For the transition to second birth, to allow for some biological limitation (see e.g., Smith et al., 2003), the process time starts at seven months after the birth of the first child. First-generation women with one child at migration enter observation at migration unless they had their first child less than seven months prior to migration. Women having their first child at least seven months before the age of 15 enter the second-birth analysis at age 15. Women having twins (or other multiple births) at first birth are not included in the second-birth analysis. Women are right-censored when they experience the event, at age 45, on December 31, 2010 (the time of the interview of the Polish stayers), or at emigration, whichever comes first.

\section{Variables}

Only biological children are taken into account in this paper. Women with no biological children are considered childless even if they have adopted children, foster children, and/or stepchildren.

Migrant group, as previously mentioned, refers to Swedish natives, first-generation Polish migrants (G1), second-generation Polish migrants (G2), and Polish stayers. In the first-birth analysis the woman's age is the process time, specified as a time-varying variable, and is split into five-year intervals starting at age 15 . In the second-birth analysis time since first birth is the process time. Two-year intervals are specified, starting at seven months after first birth. To ensure that possible differences in fertility behaviour between the groups are not caused by variation in the cohort distribution, we define a cohort variable categorised into four groups - 1950-1959, 1960-1969, 1970-1979, and 1980-1992 - as control. As marital status is an important factor in immigrants' childbearing (see e.g., Milewski, 2007), it is included in the analyses as a time-varying covariate. The categories are never married, married, and widowed/divorced. Non-marital cohabitation is not considered, as cohabiting couples cannot be identified in the registers prior to the year 2012. In the second-birth analysis, age at first birth is considered and grouped into five age groups: 15-19, 20-24, 25-29, 30-34, and 35+.

The Swedish education registers collect information on education achieved in Sweden and self-reported information on education attained abroad. The quality is high for Swedish-born individuals (both natives and the second generation), unlike for newly arrived migrants. For migrants, we find a high prevalence of missing values 
and incorrect education levels immediately after migration. The quality gradually improves over time (see Saarela and Weber 2017). For this reason, the education variable is used only for a robustness check in the event-history models and must be interpreted with caution in the descriptive analysis ${ }^{3}$. Education is categorised into low, medium, and high in accordance with Eurostat (2018), and we add the category 'in education'. In the GGS, the relevant information is extracted from a question about the respondent's current activity. In the registers, individuals with study grants and loans as their primary source of unearned income during the year and maximum earnings from work of twice the basbelopp (base amount), which corresponds to $84,800 \mathrm{SEK}^{4}$ are categorised as being in education. However, women who earned more than 84,800 SEK from work are also considered students if their study grant and loan exceeded 84,800 SEK (see Andersson \& Scott, 2005; Andersson \& Scott, 2007).

\section{Results}

\section{Descriptive overview}

Table 1 provides a descriptive overview of the population of interest (for distribution of time at risk, see Table A2 in the Supplemental Appendix). We specify two groups of first-generation migrants in order to observe whether the distribution of characteristics changes when women who have at least one child at migration or give birth in the month of arrival in Sweden are excluded. The exclusion slightly increases the shares of women in the youngest cohort, the highly educated, and single women. The share of women migrating at older ages decreases.

Comparing all five groups, we notice cohort differences. Most notably, the second generation exhibits a much higher share of individuals in the younger cohorts than the other groups do. This also explains why the proportion of individuals in education is substantially higher in this group. In terms of educational attainment, the firstgeneration migrants are the most highly educated group, while the Polish stayers are the least highly educated group. Moreover, the marital status distribution also varies greatly between the groups, partly related to age differences, particularly for the second generation. The Polish stayers have the highest share of married women at $61 \%$, whereas the share of widowed/divorced is highest among the first generation. Regarding age at migration, most of the first-generation migrants moved to Sweden between the ages of 20 and 30 .

In order to further examine the selection into migration and compositional differences, the marital status distributions for the Polish stayers aged 18-39 and the two youngest birth cohorts (1970-1979 and 1980-1992) of the first-generation migrants

\footnotetext{
${ }^{3}$ In the robustness checks, education is treated as a time-varying variable (see supplemental appendix for more information).

${ }^{4}$ The basbelopp (the base amount) is an administrative measure that most public transfers in Sweden are related to (Andersson \& Scott, 2005). It changes every year, which means that the amount of 84,800 SEK applies only to 2010. In the selection into migration analysis, we have calculated the basbelopp times two for all years.
} 
are compared in Fig. 1. For the first-generation migrants, age refers to age at migration. The Swedish natives and the second generation are compared in a similar manner. We see that migrants moving between ages 18 and 22 are married at migration to a larger extent than their peers who stay in Poland, but the proportion of married people in the older ages is higher among the stayers compared to the first generation. Hence, first-generation Polish migrant women seem to be a selected group in terms of marital status. The Swedish natives and the second generation display extremely small differences in marital status distribution for women aged 18-39.

A similar analysis is carried out with respect to educational attainment (see Fig. 2), in which age refers to age at migration for the first-generation immigrants. As men-

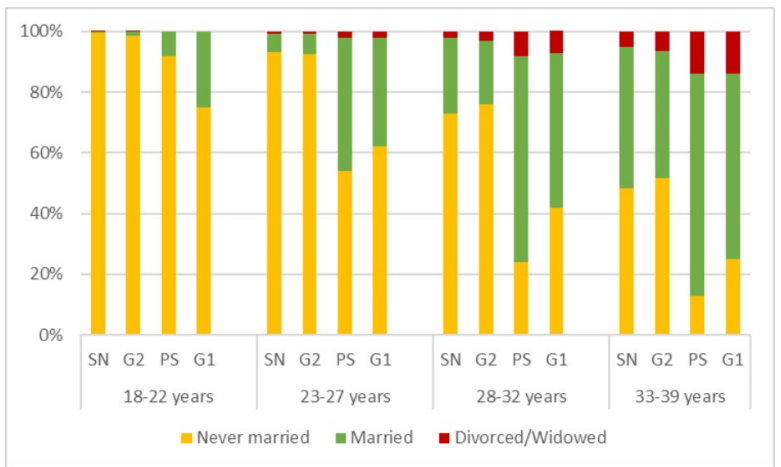

Fig. 1 Marital status by age group and migration status. Notes: Marital status for Swedish natives, secondgeneration Polish migrants, and Polish stayers aged 18-39, and for first generation at migration (19701979 and 1980-1992 cohorts). SN=Swedish natives $(760,471), \mathrm{G} 2=$ second-generation Polish immigrants $(6,345), P S=$ Polish stayers $(3,914)$, and G1 =first-generation Polish immigrants $(11,062)$. Data: Swedish register data and Polish GGS

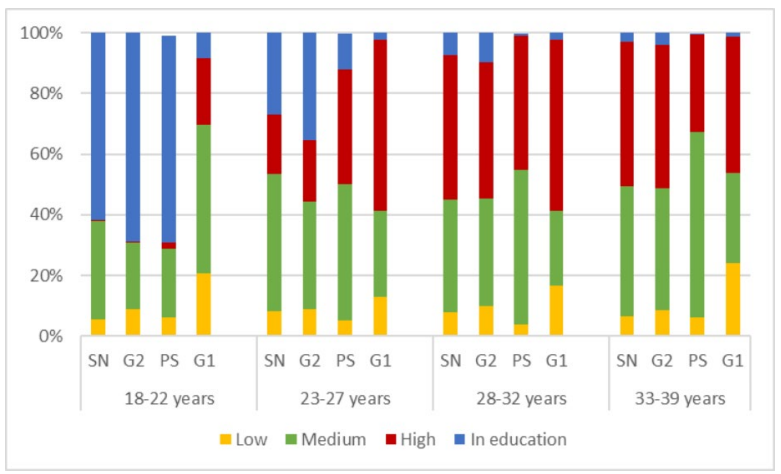

Fig. 2 Education by age group and migration status. Notes: Education distribution for Swedish natives, second-generation Polish migrants, and Polish stayers aged 18-39, and for first-generation Polish migrants at migration (1970-1979 and 1980-1992 cohorts). SN=Swedish natives $(755,255), \mathrm{G} 2=$ second-generation Polish immigrants $(6,254)$, PS $=$ Polish stayers $(3,914)$ and $\mathrm{G} 1=$ first-generation Polish immigrants (7,849). Data: Swedish register data and Polish GGS 
tioned, the education information for newly arrived migrants is somewhat problematic; hence, the comparison between Polish stayers and the first generation should be interpreted with caution. The figure indicates that the proportions of women with low and high education are larger among the first generation (at migration) compared to the stayers in the same age groups. This suggests that there is also a selection into migration based on education. As with the marital status distribution, the Swedish natives and the second generation are almost identical in terms of educational attainment, especially in the older age groups.

\section{Transition to first birth}

Figure 3 shows the Kaplan-Meier survival curves for the transition to first birth, indicating differences between the groups. Polish stayers and the first-generation migrants have their first child earlier than the other groups do. Swedish natives have their first child later than these two groups, but earlier than the second generation. The share of women estimated to remain childless also varies; more specifically, it is lowest among the first-generation migrants at only $6 \%$, followed by Polish stayers $(10 \%)$ and the Swedish natives (15\%). The second generation have the highest share estimated to remain childless, at $22 \%$. The groups differ statistically from each other.

To more thoroughly analyse the transition to first birth, baseline hazards are compared. In order to control for these sources of selectivity of migrants according to observed characteristics, we follow a stepwise approach (Table 2). In this way, we are also able to see whether these characteristics improve the model. In Model 1, only the combination between baseline and migrant group is included; we find a higher hazard ratio for the first generation and the stayers at younger ages compared to the Swedish natives and the second generation, while the two latter groups similarly peak at older ages. Adding a cohort variable in Model 2 has a very small effect. When marital status is also included in the model (Model 3), we see significant differences for all groups compared to the reference category (first-generation migrants aged 20-24). The inclusion of marital status results in a greater increase for the young Polish stayers, suggesting that marriage is important for the transition to motherhood in Poland. They peak between age 20 and 24, after which their hazard rate gradually decreases. The first generation peak at age $20-24$, similar to the Polish stayers

Fig. 3 First-birth KaplanMeier survival curves by age of woman and migrant group. Notes: G1 =first-generation Polish migrants, G2 = secondgeneration Polish migrants. Data: Swedish register data and Polish GGS

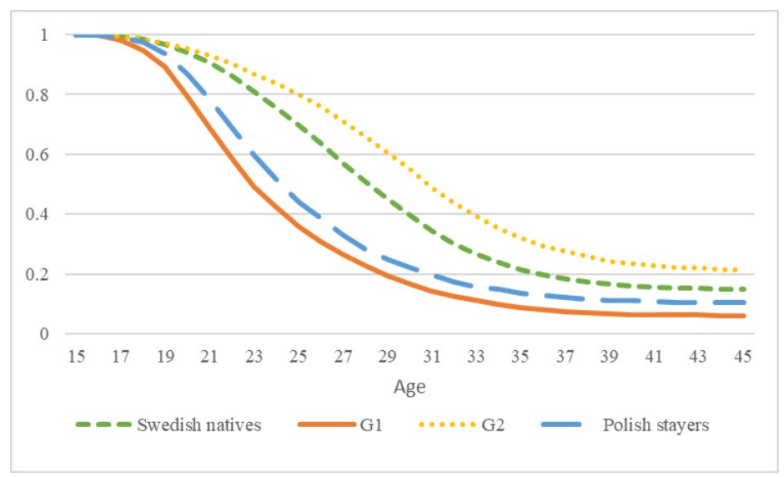


Table 2 Transition to first birth (Hazard ratios). Data: Swedish register data and Polish GGS

\begin{tabular}{|c|c|c|c|c|c|c|c|}
\hline & & Model 1 & P-value & Model 2 & P-value & Model 3 & P-value \\
\hline & $\begin{array}{l}\text { Age *migrant group } \\
(\text { ref }=G 120-24)\end{array}$ & & & & & & \\
\hline \multirow[t]{4}{*}{$15-19$} & Swedish natives & 0.075 & $<0.001$ & 0.075 & $<0.001$ & 0.195 & $<0.001$ \\
\hline & G1 & 0.420 & $<0.001$ & 0.442 & $<0.001$ & 0.834 & 0.005 \\
\hline & G2 & 0.058 & $<0.001$ & 0.070 & $<0.001$ & 0.174 & $<0.001$ \\
\hline & Polish stayers & 0.168 & $<0.001$ & 0.169 & $<0.001$ & 0.408 & $<0.001$ \\
\hline \multirow[t]{3}{*}{$20-24$} & Swedish natives & 0.368 & $<0.001$ & 0.353 & $<0.001$ & 0.807 & $<0.001$ \\
\hline & $G 2$ & 0.217 & $<0.001$ & 0.248 & $<0.001$ & 0.555 & $<0.001$ \\
\hline & Polish stayers & 0.830 & $<0.001$ & 0.827 & $<0.001$ & 1.243 & $<0.001$ \\
\hline \multirow[t]{4}{*}{$25-29$} & Swedish natives & 0.696 & $<0.001$ & 0.641 & $<0.001$ & 1.193 & $<0.001$ \\
\hline & $G 1$ & 0.971 & 0.277 & 0.917 & 0.002 & 0.839 & $<0.001$ \\
\hline & $G 2$ & 0.449 & $<0.001$ & 0.471 & $<0.001$ & 0.891 & 0.002 \\
\hline & Polish stayers & 0.876 & $<0.001$ & 0.844 & $<0.001$ & 0.929 & 0.050 \\
\hline \multirow[t]{4}{*}{$30-34$} & Swedish natives & 0.784 & $<0.001$ & 0.673 & $<0.001$ & 1.123 & $<0.001$ \\
\hline & $G 1$ & 0.817 & $<0.001$ & 0.688 & $<0.001$ & 0.649 & $<0.001$ \\
\hline & $G 2$ & 0.692 & $<0.001$ & 0.623 & $<0.001$ & 1.023 & 0.623 \\
\hline & Polish stayers & 0.628 & $<0.001$ & 0.546 & $<0.001$ & 0.599 & $<0.001$ \\
\hline \multirow[t]{13}{*}{$35+$} & Swedish natives & 0.275 & $<0.001$ & 0.219 & $<0.001$ & 0.340 & $<0.001$ \\
\hline & $G 1$ & 0.258 & $<0.001$ & 0.200 & $<0.001$ & 0.192 & $<0.001$ \\
\hline & $G 2$ & 0.306 & $<0.001$ & 0.243 & $<0.001$ & 0.397 & $<0.001$ \\
\hline & Polish stayers & 0.199 & $<0.001$ & 0.159 & $<0.001$ & 0.191 & $<0.001$ \\
\hline & \multicolumn{7}{|c|}{ Cohort $($ ref $=1970-1979)$} \\
\hline & 1950-1959 & & & 1.437 & $<0.001$ & 1.150 & $<0.001$ \\
\hline & 1960-1969 & & & 1.228 & $<0.001$ & 1.146 & $<0.001$ \\
\hline & 1980-1992 & & & 0.635 & $<0.001$ & 0.642 & $<0.001$ \\
\hline & \multicolumn{7}{|c|}{ Marital status $(\mathrm{ref}=$ married $)$} \\
\hline & Never married & & & & & 0.205 & $<0.001$ \\
\hline & Widowed/divorced & & & & & 0.260 & $<0.001$ \\
\hline & Intercept & 0.013 & & 0.013 & & 0.026 & \\
\hline & $\mathrm{n}$ & $1,776,270$ & & $1,776,270$ & & $1,776,270$ & \\
\hline
\end{tabular}

Notes: $\mathrm{SN}=$ Swedish natives, $\mathrm{G} 1=$ first generation, G2= second generation, $\mathrm{PS}=$ Polish stayers.

albeit at lower level, but seem less affected by marital status. For the Swedish natives and the second generation as well, being married is associated with a higher risk of becoming a parent. They show a pattern over time similar to that of the first group peaking at age 25-29, and the second at age 30-34, with slight differences in their baselines.

As for the other variables in the final model (Model 3) $)^{5}$, the oldest cohorts display a higher relative risk of having a first child. Moreover, the highest risk for a first child is seen for married women.

In sum, the first generation and the Polish stayers have relatively similar absolute risks in the first-birth analysis, however introducing marital status in the model affects

\footnotetext{
${ }^{5}$ Robustness checks with duration of stay, for both birth transitions, are shown for the first generation in the supplemental appendix (Table A3).
} 
the groups differently. More specifically, the risk increases for the Polish stayers, given the higher importance of marriage for first parenthood in Poland. The minor changes for the first generation due to the introduction of marital status in the model may be related to the fact that the percentage of person-time at risk is significantly higher among the first generation compared to the other groups when married (see Figure A1, Supplemental Appendix). Furthermore, the timing and quantum fertility differences between the Swedish natives and the second generation can be partly linked to cohort variations.

\section{Transition to second birth}

As the second-birth Kaplan-Meier survival curves show (see Fig. 4), the two-child norm is strong among Swedish natives. Only $12 \%$ of the women having a first child are estimated to not proceed to have a second one. We see similar patterns for the second generation, as approximately $15 \%$ will not proceed to have a second child. Among the first generation the share is substantially higher, at 27\%. We find the Polish stayers between the second and first generations, at 20\%. The groups statistically differ from each other.

The stepwise inclusion (Table 3) indicates a small impact on the combination between migrant group and baselines of the other covariates. Once again, the fertility patterns of the first generation and the stayers are quite similar, as are those of the Swedish natives and the second generation. The first generation and the Polish stayers have a significantly lower risk of having a second child, and when we control for marital status (Models 3 and 4) the differences between the two groups are further reduced. In contrast, Swedish natives and the second generation have similar patterns in terms of timing and intensity. The highest hazard ratio is seen at two to three years after the first birth for all groups. However, the differences between hazard rates at various time episodes are smaller for the first generation and the Polish stayers. For the Swedish natives and the second generation, the second birth is more concentrated to this time episode (i.e., 2-3 years). Looking at the controls, we can summarise that all cohorts have lower risks of having a second child compared to the 1970-1979 cohort. Similar to the first-birth transition, married women have a higher risk of having a second child compared to the never-married and divorcees/widows. However,

Fig. 4 Second-birth KaplanMeier survival curves by years since first birth and migrant group. Notes: G1 = first-generation Polish migrants, G2=second-generation Polish migrants. Data: Swedish register data and Polish GGS

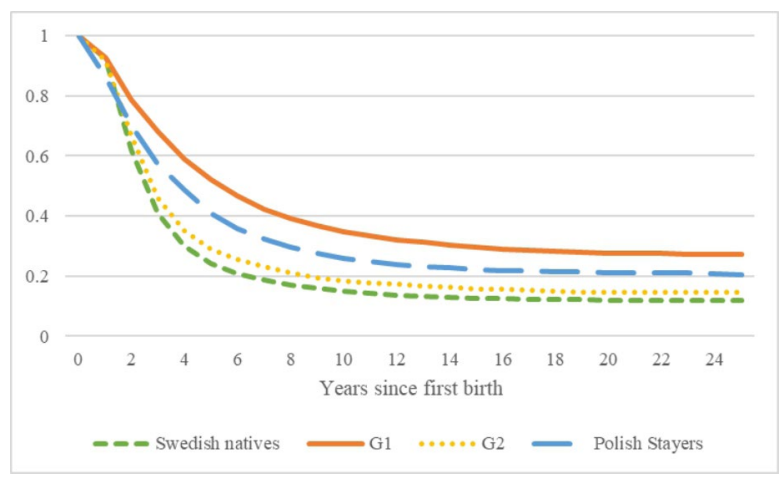


Table 3 Transition to second birth (hazard ratios). Data: Swedish register data and Polish GGS

\begin{tabular}{|c|c|c|c|c|c|c|c|c|c|}
\hline & & Model 1 & P-value & Model 2 & P-value & Model 3 & P-value & Model 4 & P-value \\
\hline & $\begin{array}{l}\text { Years since first } \\
\text { birth } * \text { migrant } \\
\text { group }(\text { ref }=2-3 \\
\text { G1) }\end{array}$ & & & & & & & & \\
\hline \multirow[t]{4}{*}{$0-1$} & Swedish natives & 1.479 & $<0.001$ & 1.440 & $<0.001$ & 1.635 & $<0.001$ & 1.626 & $<0.001$ \\
\hline & G1 & 0.810 & $<0.001$ & 0.808 & $<0.001$ & 0.772 & $<0.001$ & 0.777 & $<0.001$ \\
\hline & G2 & 1.271 & $<0.001$ & 1.250 & $<0.001$ & 1.384 & $<0.001$ & 1.399 & $<0.001$ \\
\hline & Polish stayers & 1.203 & $<0.001$ & 1.159 & $<0.001$ & 1.013 & 0.716 & 0.973 & 0.437 \\
\hline \multirow[t]{3}{*}{$2-3$} & Swedish natives & 2.622 & $<0.001$ & 2.579 & $<0.001$ & 3.012 & $<0.001$ & 3.009 & $<0.001$ \\
\hline & $G 2$ & 2.285 & $<0.001$ & 2.261 & $<0.001$ & 2.612 & $<0.001$ & 2.628 & $<0.001$ \\
\hline & Polish stayers & 1.272 & $<0.001$ & 1.216 & $<0.001$ & 1.076 & 0.069 & 1.032 & 0.433 \\
\hline \multirow[t]{4}{*}{$4-5$} & Swedish natives & 1.282 & $<0.001$ & 1.268 & $<0.001$ & 1.555 & $<0.001$ & 1.568 & $<0.001$ \\
\hline & $G 1$ & 0.825 & $<0.001$ & 0.826 & $<0.001$ & 0.871 & $<0.001$ & 0.866 & $<0.001$ \\
\hline & $G 2$ & 1.155 & 0.043 & 1.152 & 0.048 & 1.442 & $<0.001$ & 1.449 & $<0.001$ \\
\hline & Polish stayers & 1.087 & 0.092 & 1.034 & 0.505 & 0.938 & 0.194 & 0.897 & 0.029 \\
\hline \multirow[t]{18}{*}{$6+$} & Swedish natives & 0.359 & $<0.001$ & 0.362 & $<0.001$ & 0.454 & $<0.001$ & 0.440 & $<0.001$ \\
\hline & G1 & 0.300 & $<0.001$ & 0.304 & $<0.001$ & 0.357 & $<0.001$ & 0.341 & $<0.001$ \\
\hline & $G 2$ & 0.344 & $<0.001$ & 0.352 & $<0.001$ & 0.452 & $<0.001$ & 0.438 & $<0.001$ \\
\hline & Polish stayers & 0.345 & $<0.001$ & 0.332 & $<0.001$ & 0.324 & $<0.001$ & 0.306 & $<0.001$ \\
\hline & $\begin{array}{l}\text { Cohort } \\
(\text { ref }=1970-1979)\end{array}$ & & & & & & & & \\
\hline & 1950-1959 & & & 0.784 & $<0.001$ & 0.703 & $<0.001$ & 0.705 & $<0.001$ \\
\hline & 1960-1969 & & & 0.946 & $<0.001$ & 0.915 & $<0.001$ & 0.938 & $<0.001$ \\
\hline & 1980-1992 & & & 0.794 & $<0.001$ & 0.853 & $<0.001$ & 0.815 & $<0.001$ \\
\hline & $\begin{array}{l}\text { Marital status } \\
\text { (ref=married) }\end{array}$ & & & & & & & & \\
\hline & Never married & & & & & 0.581 & $<0.001$ & 0.576 & $<0.001$ \\
\hline & $\begin{array}{l}\text { Widowed/ } \\
\text { divorced }\end{array}$ & & & & & 0.377 & $<0.001$ & 0.381 & $<0.001$ \\
\hline & $\begin{array}{l}\text { Age at first birth } \\
(\mathrm{ref}=20-24)\end{array}$ & & & & & & & & \\
\hline & $15-19$ & & & & & & & 0.900 & $<0.001$ \\
\hline & $25-29$ & & & & & & & 0.984 & $<0.001$ \\
\hline & $30-34$ & & & & & & & 0.816 & $<0.001$ \\
\hline & $35+$ & & & & & & & 0.444 & $<0.001$ \\
\hline & Intercept & 0.012 & & 0.014 & & 0.017 & & 0.018 & \\
\hline & $\mathrm{n}$ & $1,078,522$ & & $1,078,522$ & & $1,078,522$ & & $1,078,522$ & \\
\hline
\end{tabular}

Notes: $\mathrm{SN}=$ Swedish natives, $\mathrm{G} 1=$ first generation, $\mathrm{G} 2=$ second generation, $\mathrm{PS}=$ Polish stayers.

the differences are substantially smaller in the second-birth transition compared to the first-birth transition. We find the highest risk of having a second child among women who had their first child in the 20-24 age group.

In short, the first generation's baseline is highly similar to that of the Polish stayers, and when the marital status variable is included the two groups seem to become even more similar. In addition, as the risk for the Swedish natives and the second generation increases when marital status is included, they become even less similar to the Polish stayers and the first generation. 


\section{Discussion and conclusions}

The aim of our study was to deepen the knowledge about a group that has received less attention in migrant fertility research, namely migrants moving from a low-fertility setting to a country with higher fertility levels. We applied the relatively rare, combined country-of-origin and country-of-destination approach, seeking a more solid test of the socialisation, selection, and adaptation hypotheses.

First, in line with the socialisation hypothesis, we hypothesized that first-generation migrants and Polish stayers would have similar fertility behaviour (H1). We indeed find some similarities, like in previous studies (e.g., Milewski, 2010a; Mussino \& Strozza, 2012), and these apply particularly to the transition to the second child.

According to our second hypothesis, the differences in fertility behaviour of the first generation compared to that of the Polish stayers (H2a) and the Swedish natives (H2b) can be partly linked to selection into migration and the composition of the migrant group. Our analysis suggests that first-generation Polish migrants are selected into migration based on marital status and education. As fertility differences by educational attainment have been found among second-generation Polish migrants in Sweden (Scott \& Stanfors, 2011), this is also likely to apply to the first generation. The larger share of highly educated among the first generation might therefore partly explain the lower share among them proceeding to have a second child. When marital status is included in the first-birth analysis, the fertility levels of the first generation and of the stayers become more different in some age groups and more similar in others, although the timing remains similar. In the second-birth analysis, the fertility level difference between the two groups is much smaller. In sum, our findings suggest that selection can explain both differences and similarities among the groups. Given the varying effect of the control variables, $H 2 a$ and $b$ are partly supported and partly rejected, similar to Baykara-Krumme and Miliewski's (2017) findings. Furthermore, our study shows that the impact of marriage varies between stayers and migrants, in both birth transitions, suggesting a selection into migration even when it comes to unobserved characteristics, for instance their view on having children outside marriage. Conversely, our results in the first-birth analysis show that including marital status increases the difference between the Swedish natives and the first generation. Hence, similar to the findings in $H 2 a$, selection seems to work in two directions, partly supporting and partly rejecting this hypothesis.

Finally, the third hypothesis (H3) was developed in line with the adaptation hypothesis and stated that there should be a convergence in fertility behaviour across migrant generations. In the first-birth analysis, the fertility behaviour of the second generation resembles that of Swedish natives rather than that of Polish stayers. In the second-birth analysis the fertility behaviours seem to converge even more across migrant generations, in terms of both timing and quantum. The convergence across migrant generations resembles findings from previous research (e.g., Scott \& Stanfors, 2011). With respect to social policies, the speed premium has been shown to affect the birth spacing of Swedish natives as well as Nordic-born individuals living in Sweden (Andersson et al., 2006), and here we find a similar pattern for secondgeneration Polish women. Such convergence across migrant generations may be 
considered a sign of social policy adaptation, and in line with previous literature it also suggests adaptation to labour market regulations and the dominant culture in the country of destination (Andersson, 2004; Kulu \& González-Ferrer, 2014; Milewski, 2007).

This study has some limitations, however. Firstly, as the Polish GGS sample is not fully representative of the population it is impossible to rule out potential differences between the groups, for example regarding fertility patterns. However, as mentioned, the use of weights partially corrected this problem. Secondly, the study considers education selection only descriptively, even though previous research (e.g., Scott \& Stanfors, 2011) has shown that education matters for the fertility behaviour of second-generation Polish migrants in Sweden. As the share of missing values was high for the first generation (27\%), we decided not to include education in the main analysis. Additional analyses have been carried out as robustness checks, presented in the supplemental appendix, in which all patterns are confirmed. Thirdly, working with Swedish registers we should account for over-coverage, but as indicated in a previous study (Monti et al., 2020) this affects only approximately 7\% of Eastern European migrants in 2010. Fourthly, our study does not aim to explain the mechanisms behind Polish women's fertility but rather to gain a better understanding of how theories and hypotheses on migrants' fertility apply here, given the importance of the initial testing of falsifiable predictions (see e.g., Wilson, 2019).

Bearing in mind these limitations, we conclude that our paper contributes to the field of immigrant fertility research in multiple ways. To start with, relying on a combination of the country-of-origin and country-of-destination approach made it possible to compare first-generation migrants with several other groups in order to test the adaptation and socialisation hypotheses more thoroughly than has been done in most previous research. We demonstrated compositional and fertility-level differences among the first generation and the stayers, highlighting that it can be misleading to draw conclusions regarding socialisation while not considering fertility behaviour in the sending country in the analysis. This underlines the importance of including stayers in future research on immigrant fertility. Furthermore, our study has extended knowledge about the fertility behaviour of migrants moving from a country with low fertility to a country with higher fertility. Finally, it has complemented previous research on Polish migrant women (inspired by Lübke, 2015) by adding information about the medium-/long-term effects of migration on their fertility behaviour. Our findings confirm that first-generation Polish migrants' behaviour is more similar to that of stayers compared to natives in the destination country when it comes to the timing of events. Some unexpected dissimilarities can be explained by both the composition of the migrant group and unobserved preferences. Thus, the selection effect can work in two directions, explaining some of the differences as well as some of the similarities in fertility. Convergence across migrant generations in terms of timing and quantum is also supported, particularly with respect to the second child. Swedish multiculturalism seems to accommodate first-generation migrant women's preferences, in terms of similarities in the timing of both first and second births to their peers in the country of origin. However, the birth spacing and quantum convergence across migrant generations suggest that exposure to the Swedish society and policy context also affects their longer-term fertility behaviour. 
Supplementary Information The online version contains supplementary material available at https://doi. org/10.1007/s12546-022-09283-7.

Funding Open access funding provided by Stockholm University. This research was supported by the Swedish Research Council for Health, Working Life and Welfare (FORTE), grant number 2018-00310.

Open Access This article is licensed under a Creative Commons Attribution 4.0 International License, which permits use, sharing, adaptation, distribution and reproduction in any medium or format, as long as you give appropriate credit to the original author(s) and the source, provide a link to the Creative Commons licence, and indicate if changes were made. The images or other third party material in this article are included in the article's Creative Commons licence, unless indicated otherwise in a credit line to the material. If material is not included in the article's Creative Commons licence and your intended use is not permitted by statutory regulation or exceeds the permitted use, you will need to obtain permission directly from the copyright holder. To view a copy of this licence, visit http://creativecommons.org/licenses/by/4.0/.

\section{References}

Abbasi-Shavazi, M. J., \& McDonald, P. (2000). Fertility and multiculturalism: Immigrant fertility in Australia, 1997-1991. International Migration Review, 34(1), 215-242

Adserá, A., \& Ferrer, A. (2015). Immigrants and demography: Marriage, divorce and fertility. Handbook of the economics of international migration, 1, 315-374

Adserá, A., Ferrer, A., Sigle-Rushton, W., \& Wilson, B. (2012). Fertility patterns of child migrants: Age at migration and ancestry in comparative perspective. The Annals of the American Academy of Political and Social Science, 643(1), 160-189

Andersson, G. (2004). Childbearing after migration: Fertility patterns of foreign-born women in Sweden. International Migration Review, 38(2), 747-775

Andersson, G., Hoem, J., \& Duvander, A. Z. (2006). Social differentials in speed-premium effects in childbearing in Sweden. Demographic Research, 14, 51-70

Andersson, G., Persson, L., \& Obućina, O. (2017). Depressed fertility among descendants of immigrants in Sweden. Demographic Research, 36(39), 1149-1184

Andersson, G., \& Scott, K. (2005). Labour-market status and first-time parenthood: The experience of immigrant women in Sweden, 1981-97. Population Studies, 59(1), 21-38

Andersson, G., \& Scott, K. (2007). Childbearing dynamics of couples in a universalistic welfare state: The role of labour-market status, country of origin, and gender. Demographic Research, 17(30), 897-938

Bagavos, C., Tsimbos, C., \& Verropoulou, G. (2008). Native and migrant fertility patterns in Greece: A cohort approach. European Journal of Population, 24(3), 245-263

Baykara-Krumme, H., \& Milewski, N. (2017). Fertility patterns among Turkish women in Turkey and abroad: The effects of international mobility, migrant generation, and family background. European Journal of Population, 33(3), 409-436

Bengtsson, T. (2008). Förändrat flyttmönster från Polen. Fokus på näringsliv och arbetsmarknad. Information om arbetsmarknad (2.). Statistics Sweden

Billingsley, S., \& Matysiak, A. (2018). Social mobility and family expansion in Poland and Russia during socialism and capitalism. Advances in Life Course Research, 36, 80-91

Blau, F. (1992). The fertility of immigrant women: Evidence from high-fertility source countries. In J. George, \& R. Freeman (Eds.), Immigration and the work force: Economic consequences for the United States and source areas (pp. 93-133). Chicago and London: The University of Chicago Press

Blossfeld, H. P., Golsch, K., \& Rohwer, G. (2007). Event history analysis with Stata. Lawrence Erlbaum

Carlsson, E. (2019). Fertility intentions across immigrant generations in Sweden: Do patterns of adaptation differ by gender and origin? Comparative Population Studies, 43, 211-242

Castles, S., De Haas, H., \& Miller, M. (2014). The age of migration: International population movements in the modern world. Guilford Publications

Choi, K. H. (2014). Fertility in the context of Mexican migration to the United States: A case for incorporating the pre-migration fertility of immigrants. Demographic Research, 30, 703-738

Coale, A., \& Trussell, T. (1974). Model fertility schedules: Variations in the age structure of childbearing in human populations. Population Index, 40(2), 185-258 
Coleman, D. (1994). Trends in fertility and intermarriage among immigrant populations in Western Europe as measure of integration. Journal of Biosocial Science, 26, 107-136

Dubuc, S. (2012). Immigration to the UK from high-fertility countries: Intergenerational adaptation and fertility convergence. Population and Development Review, 38(2), 353-368

Eurostat (2018). International Standard Classification of Education (ISCED). https://ec.europa.eu/eurostat/statistics-explained/index.php/International_Standard_Classification_of_Education_(ISCED)

Eurostat (2019). Migration and migrant population statistics.http://ec.europa.eu/eurostat/statisticsexplained/index.php/Migration_and_migrant_population_statistics

Eurostat (2020). Population on 1 January by age group, sex and country of birth. http://appsso.eurostat. ec.europa.eu/nui/submitViewTableAction.do

Eurostat (2021). Fertility indicators. https://ec.europa.eu/eurostat/databrowser/view/demo_find/default/ table?lang=en

Fahlén, S., \& Oláh, L. (2013). Work and childbearing intentions from a capability perspective: Young adult women in Sweden. In F. Oláh (Ed.), Childbearing, women's employment and work-life balance policies in contemporary Europe (pp. 28-64). Basingstoke: Palgrave Macmillan

Fokkema, T., Emery, T., Kveder, A., Liefbroer, A., \& Hiekel, N. (2016). Generations and Gender Programme Wave 1 data collection: An overview and assessment of sampling and fieldwork methods, weighting procedures, and cross-sectional representativeness. Demographic Research, 34(18), 499-524

Frank, R., \& Heuveline, P. (2005). A crossover in Mexican and Mexican-American fertility rates: Evidence and explanations for an emerging paradox. Demographic Research, 12(4), 77-104

Glick, J. (2010). Connecting complex processes: A decade of research on immigrant families. Journal of Marriage and Family, 72(3), 498-515

Gołata, E. (2016). Estimation of fertility in Poland and of Polish born women in the United Kingdom. Studia Demograficzne, 1(169), 13-38. DOI:https://doi.org/10.33119/SD.2016.1.1

Goldstein, S., \& Goldstein, A. (1983). Migration and fertility in Peninsular Malaysia: An analysis using life history data. Santa Monica, CA: Rand Corporation

Grzenda, W., \& Frątczak, E. (2018). Cohort patterns of fertility in Poland based on staging processgenerations 1930-1980. Statistics in Transition New Series, 19(2), 315-330. DOI: https://doi. org/10.21307/stattrans-2018-018

Guarin Rojas, Bernardi, L., \& Schmid, F. (2018). First and second births among immigrants and their descendants in Switzerland. Demographic Research, 38(11), 247-286

Güveli, A., Ganzeboom, H., Platt, L., Nauck, B., Baykara-Krumme, H., Eroglu, S. ... Eroğlu-Hawskworth, Ş. (2016). Intergenerational consequences of migration: Socio-economic, family and cultural patterns of stability and change in Turkey and Europe. Springer

Hoem, J. M., \& Nedoluzhko, L. (2016). The dangers of using 'negative durations' to estimate pre- and post-migration fertility. Population Studies, 70(3), 359-363. https://doi.org/10.1080/00324728.201 6.1221442

Hort, S. E., Kings, L., \& Kravchenko, Z. (2016). Still awaiting the storm? The Swedish welfare state after the latest crisis. Challenges to European welfare systems (pp. 671-691). Cham: Springer

Impicciatore, R., Gabrielli, G., \& Paterno, A. (2020). Migrants' fertility in Italy: A comparison between origin and destination.European Journal of Population, 1-27

Jalovaara, M., Neyer, G., Andersson, G., Dahlberg, J., Dommermuth, L., Fallesen, P., \& Lappegård, T. (2019). Education, gender and cohort fertility in the Nordic countries. European Journal of Population, 35, 563-586

Kahn, J. (1988). Immigrant selectivity and fertility adaptation in United States. Social Forces, 67(1), $108-128$

Kaufman, G., Bernhardt, E., \& Goldscheider, F. (2017). Enduring egalitarianism? Family transitions and attitudes towards gender equality in Sweden. Journal of Family Issues, 38(13), 1878-1898

Klimek, L. (2017). Migration and fertility. Polish migrant families in Ireland and non-migrant families in Poland: A comparison of fertility plans and behaviour. Central and Eastern European Migration Review, 6(2), 5-30

Klinthäll, M. (2006). Retirement return migration from Sweden. International Migration, 44(2), 153-180

Klinthäll, M. (2007). Refugee return migration: Return migration from Sweden to Chile, Iran and Poland 1973-1996. Journal of Refugee Studies, 20(4), 579-598

Kotowska, I., Józwiak, J., Mynarska, M., \& Katarzyna, K. G. (2019). Generations and Gender Survey Poland Wave 1 \& Wave 2: Study Documentation \& Wave 2 File and Variables Descriptions.https:// www.ggp-i.org/wp-content/uploads/2019/07/GGS_W1W2_Poland.pdf 
Kulu, H., Vikat, A., \& Andersson, G. (2007). Settlement size and fertility in the Nordic countries. Population Studies, 61(3), 265-285

Kulu, H., \& González-Ferrer, A. (2014). Family dynamics among immigrants and their descendants in Europe: Current research and opportunities. European Journal of Population, 30(4), 411-435

Kulu, H., Hannemann, T., Pailhé, A., Neels, K., Krapf, S., González-Ferrer, A., \& Andersson, G. (2017). Fertility by birth order among the descendants of immigrants in selected European countries. Population Development Review, 43(1), 31-60

Kulu, H., \& Hannemann, T. (2016). Why does fertility remain high among certain UK-born ethnic minority women? Demographic Research, 35(49), 1441-1488

Kulu, H., Milewski, N., Hannemann, T., \& Mikolai, J. (2019). A decade of life-course research on fertility of immigrants and their descendants in Europe. Demographic Research, 40, 1345-1374

Lessard-Phillips, L., Galandini, S., de Valk, H., \& Fibbi, R. (2017). Damned if you do, damned if you don't: The challenges of including and comparing the children of immigrants. In C. Bolzman, L. Bernardi, \& Le J. M. Goff (Eds.), Situating children of migrants across borders and origins. Life Course Research and Social Policies 7 (pp. 25-53). Dordrecht: Springer

Lesthaeghe, R. (2011). The 'Second demographic transition': A conceptual map for the understanding of late modern demographic developments in fertility and family formation. Historical Social Research, 36(2), 179-218

Lindstrom, D. P., \& Saucedo, S. G. (2002). The short- and long-term effects of US migration experience on Mexican women's fertility. Social Forces, 80(4), 1341-1368

Lindstrom, D. P., \& Saucedo, S. G. (2007). The interrelationship between fertility, family maintenance, and Mexico-US migration. Demographic Research, 17, 821-858

Lübke, C. (2015). How migration affects the timing of childbearing: The transition to a first birth among Polish Women in Britain. European Journal of Population, 31(1), 1-20

Macisco, J., Bouvier, L., \& Renzi, M. (1969). Migration status, education and fertility in Puerto Rico, 1960. The Milbank Memorial Fund Quarterly, 47(2), 167-186

Marczak, J., Sigle, W., \& Coast, E. (2018). When the grass is greener: Fertility decisions in a cross-national context. Population Studies, 72(2), 201-216

Massey, D. S., \& Mullan, B. P. (1984). Processes of Hispanic and black spatial assimilation. American Journal of Sociology, 89(4), 836-873

Matysiak, A., \& Vignoli, D. (2013). Diverse effects of women's employment on fertility: Insights from Italy and Poland. European Journal of Population, 29(3), 273-302

Milewski, N. (2007). First child of immigrant workers and their descendants in West Germany: Interrelation of events, disruption, or adaptation? Demographic Research, 17(29), 859-895

Milewski, N. (2010a). Immigrant fertility in West Germany: Is there a socialization effect in transitions to second and third births? European Journal of Population, 26(3), 297-323

Milewski, N. (2010b). Fertility of immigrants: A two-generational approach in Germany. Berlin: Springer

Milewski, N. (2011). Transition to a first birth among Turkish second-generation migrants in Western Europe. Advances in Life Course Research, 16(4), 178-189

Milewski, N., \& Mussino, E. (2018). Editorial on the Special Issue "New Aspects on Migrant Populations in Europe: Norms, Attitudes and Intentions in Fertility and Family Planning. Comparative Population Studies, 43, 371-398

Mills, M. (2011). Introducing survival and event history analysis. London: SAGE Publications Ltd.

Monti, A., Drefahl, S., Mussino, E., \& Härkönen, J. (2020). Over-coverage in population registers leads to bias in demographic estimates. Population Studies, 74(3), 451-469

Mussino, E., Miranda, V., \& Ma, L. (2018). Changes in sex ratio at birth among immigrant groups in Sweden. Genus, 74(1), 13

Mussino, E., \& Strozza, S. (2012). The fertility of immigrants after arrival: The Italian case. Demographic Research, 26(4), 97-130

Mussino, E., Wilson, B., \& Andersson, G. (2021). The fertility of immigrants from low-fertility settings: Adaptation in the quantum and tempo of childbearing? Demography, online first DOI: https://oi. org/10.1215/00703370-9476273

Nahmias, P. (2004). Fertility behaviour of recent immigrants to Israel: A comparative analysis of immigrants from Ethiopia and the former Soviet Union. Demographic Research, 10(4), 83-120

Neyer, G. (2013). Welfare states, family policies, and fertility in Europe. In G. Neyer, G. Andersson, H. Kulu, L. Bernardi, \& C. Bühler (Eds.), The Demography of Europe (pp. 29-53). Dordrecht: Springer 
OECD (2018). OECD Family Database: The structure of families (SF): SF2.4 Share of births outside of marriage. Data Chart Births_outside_marriage. Share of births outside of marriage. http://www.oecd. org/els/family/database.htm

OECD (2019). OECD Family Database: Public Policies for families and children (PF): PF1.1 Public spending on family benefits. Data Chart PF1. 1.A. Public spending on family benefits. http://www. oecd.org/els/family/database.htm

OECD (2020). International Migration Database.https://stats.oecd.org/Index.aspx?DataSetCode=MIG

Pailhé, A. (2017). The convergence of second-generation immigrants' fertility patterns in France: The role of sociocultural distance between parents' and host country. Demographic Research, 36(45), 1361-1398

Parrado, E. A. (2011). How high is Hispanic/Mexican fertility in the United States? Immigration and tempo considerations. Demography, 48(3), 1059-1080

Puur, A., Rahnu, L., Abuladze, L., Sakkeus, L., \& Zakharov, S. (2017). Childbearing among first—and second-generation Russians in Estonia against the background of the sending and host countries. Demographic Research, 36(41), 1209-1254

Rumbaut, R. (2004). Ages, life stages, and generational cohorts: Decomposing the immigrant first and second generations in the United States. International Migration Review, 38(3), 1160-1205

Saarela, J., \& Weber, R. (2017). Assessment of educational misclassification in register-based data on Finnish immigrants in Sweden. Scandinavian Journal of Public Health, 45(17), 20-24

Schoenmaekers, R., Lodewijckx, E., \& Gadeyne, S. (1999). Marriages and fertility among Turkish and Moroccan women in Belgium: Results from census data. International Migration Review, 33(4), 901-928

Scott, K., \& Stanfors, M. (2011). The transition to parenthood among the second generation: Evidence from Sweden, 1990-2005. Advances in Life Course Research, 16(4), 190-204

Siemieńska, R., \& Domaradzka, A. (2016). Between constrained opportunities and social expectations: Social policy in contemporary Poland. Challenges to European Welfare Systems (pp. 563-586). Cham: Springer

Smith, G. C. S., Pell, J. P., \& Dobbie, R. (2003). Interpregnancy interval and risk of preterm birth and neonatal death: retrospective cohort study. $B M J, 327,313$

Sobotka, T. (2008). Overview Chap. 7: The rising importance of migrants for childbearing in Europe. Demographic Research, 19(9), 225-248

Statistics Sweden (2010). Born in Sweden-but still different? The significance of parents' country of birth. Demografiska rapporter 2010:2

Statistics Sweden (2012). Background material about demography, children and family 2012:1. The significance of time in Sweden on fertility. https:/www.scb.se/contentassets/0bbc2d0826d1457591fac8 0777f352be/be0401_2000i09_br_be52br1201.pdf

Statistics Sweden (2018). Nedåtgående trend i barnafödande.

https://www.scb.se/hitta-statistik/artiklar/2018/nedatgaende-trend-i-barnafodande/

Szelewa, D. (2017). From implicit to explicit familialism: Post-1989 family policy reforms in Poland. In D. Auth, \& H. J. Holland-Cunz B. (Eds.), Gender and family in European economic policy (pp. 129-151). Cham: Palgrave Macmillan

Tomescu-Dubrow, I., Dubrow, J. K., Kiersztyn, A., Andrejuk, K., Kołczyńska, M., \& Slomczynski, K. M. (2019). Economic context, labor market situation, and employment policies. The Subjective Experience of Joblessness in Poland (pp. 13-40). Cham: Springer

Tønnessen, M., \& Mussino, E. (2020). Fertility patterns of migrants from low-fertility countries in Norway. Demographic Research, 42(31), 859-874

Tønnessen, M., \& Wilson, B. (2020). Visualising immigrant fertility_Profiles of childbearing and their implications for migration research. Journal of International Migration and Integration. https://oi. org/10.1007/s12134-020-00762-5

Van Landshoot, L., de Valk, H. A. G., \& Van Bavel, J. (2017). Fertility among descendants of immigrants in Belgium: The role of the partner. Demographic Research, 36(60), 1827-1858

Vignoli, D., Matysiak, A., Styrc, M., \& Tocchioni, V. (2018). The positive impact of women's employment on divorce: Context, selection, or anticipation? Demographic Research, 38(37), 1059-1110

Waller, L., Berrington, A., \& Raymer, J. (2014). New insights into the fertility patterns of recent Polish migrants in the United Kingdom. Journal of Population Research, 31, 131-150. https://doi. org/10.1007/s 12546-014-9125-5 
Wells, M. B., \& Bergnehr, D. (2014). Families and family policies in Sweden. In M. Robila (Ed.), Handbook of family policies across the globe. New York, NY: Springer. https://doi. org/10.1007/978-1-4614-6771-7_7

Wilson, B. (2013). Disentangling the quantum and tempo of immigrant fertility. Paper presented at the 7th International Conference on Population Geographies in Groningen, The Netherlands, 25-28 June 2013

Wilson, B. (2019). The intergenerational assimilation of completed fertility: Comparing the convergence of different origin groups. International Migration Review, 53(2), 429-457. https://oi. org/10.1177/0197918318769047

Publisher's Note Springer Nature remains neutral with regard to jurisdictional claims in published maps and institutional affiliations. 